\title{
Printing Patches for Diseased Hearts
}

\section{Coming Events}

\section{9}

NextTEM: Next-Generation

Transmission Electron

Microscopy Workshop

August 4, 2019

Portland, OR

www.microscopy.org/MandM/2019/program/ NexTEM_2019_Announcement.pdf

Microscopy \& Microanalysis 2019

August 4-8, 2019

Portland, OR

www.microscopy.org

Denver X-Ray Conference

August 5-9, 2019

Lombard, IL

www.dxcicdd.com

\section{MC2019 Microscopy Conference}

September 1-5, 2019

Berlin, Germany

www.microscopy-conference.de

National Society for Histology, 45th

Annual Symposium

September 20-25, 2019

New Orleans, LA

www.histoconvention.org/futuredates.cfm

Interdisciplinary Symposium on 3D Microscopy

October 1-4, 2019

Engelberg, Switzerland

www.3dssom2019.ch

\section{Neuroscience 2019}

October 19-23, 2019

Chicago, IL

Sponsor: Society for Neuroscience

www.sfn.org

\section{0}

Microscopy \& Microanalysis 2020

August 2-6, 2020

Milwaukee, WI

www.microscopy.org

\section{1}

Microscopy \& Microanalysis 2021

August 1-5, 2021

Pittsburgh, PA

www.microscopy.org

\section{2}

Microscopy \& Microanalysis 2022

July 31-August 4, 2022

Portland, OR

www.microscopy.org

\section{3}

Microscopy \& Microanalysis 2023

July 24-28, 2023

Minneapolis, MN

www.microscopy.org

\section{4}

Microscopy \& Microanalysis 2024

July 28-August 1, 2024

Cleveland, $\mathrm{OH}$

www.microscopy.org

More Meetings and Courses

Check the complete calendar near the back of this magazine.

\author{
Stephen W. Carmichael \\ Mayo Clinic, Rochester, MN 55905 \\ carmichael.stephen@mayo.edu
}

Cardiovascular diseases are the number one cause of death in industrialized countries. To date, heart transplantation is the only treatment available for patients with end-stage cardiac failure. Many of these patients die while waiting for a suitable donor heart; therefore, there is a need to develop new approaches to regenerate cardiac muscle that has infarcted. Since, in theory, only the infarcted portion needs to be replaced, a functional "patch" may be all that is needed to restore cardiac function to a survivable level. Tissue engineering of cardiac tissue provides such an approach by integrating cardiac cells and $3 \mathrm{D}$ biomaterials. The latter serve as temporary scaffolds, mechanically supporting the cells and promoting their reorganization into a functional tissue. This could be fashioned in vitro until the patch is mature enough to be transplanted onto the infarction site. After integration into the host commences, the biomaterials gradually degrade leaving a functional living patch that restores cardiac function. Recently Nadav Noor, Assaf Shapira, Reuven Edri, Idan Gal, Lior Wertheim, and Tal Dvir developed a thick and perfusable cardiac patch, using 3D printing, that shows much promise for treating end-stage cardiac failure [1].

The biocompatibility of the scaffolding materials is a crucial factor for eliminating the risk of implant rejection, which in turn jeopardizes the success of the treatment. Therefore, Noor et al. developed a method to use autologous tissue for the scaffold. They took adipose tissue from the omentum of either patients or pigs. Then the cellular and acellular materials were separated. While the cells were reprogrammed to become pluripotent stem cells and differentiated into cardiac
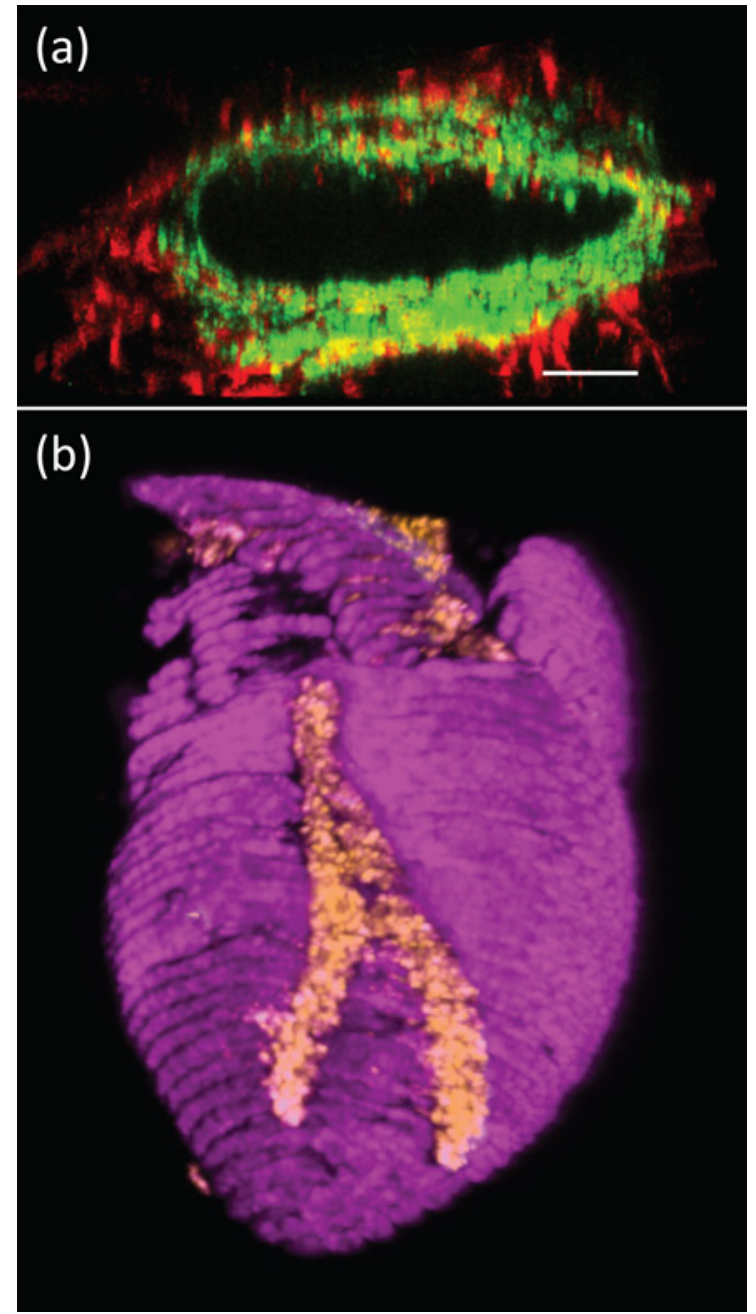

Figure 1: (a) Fluorescence microscopy image of a 3D-printed blood vessel cross section showing the interactions of green fluorescent protein (expressing endothelial cells) and red fluorescent protein (expressing fibroblasts). Bar $=100 \mu \mathrm{m}$. (b) Confocal image of a 3D-printed heart (cardiac myocytes in pink, endothelial cells in orange). Width of heart $=6 \mathrm{~mm}$. 


\section{COMING UP ON 50 YEARS OF DEVELOPMENT, MANUFAGTURING, AND GUSTOMER SERVICE...}

\section{...and still innovating}

Free customer service

Sectioning tests with biological and material research specimens of all kinds. We send you the sections along with the surfaced sample, a report on the results obtained and a recommendation of a suitable knife. Complete discretion when working with proprietary samples.

Re-sharpening and reworking service

A re-sharpened Diatome diamond knife demonstrates the same high quality as a new knife. Even knives purchased in previous years can continue to be re-sharpened. The knives can be reworked into another type of knife for no extra charge, e.g. ultra to cryo or $45^{\circ}$ to $35^{\circ}$.

\section{Exchange service}

Whenever you exchange a knife we offer you a new Diatome knife at an advantageous price.

\section{DHATOME diamond knives}

ultra $45^{\circ} \cdot$ cryo - histo - ultra $35^{\circ}$ histo jumbo • STATIC LWNE II • cryo immuno ultra sonic 0 ultira AFM \& Gryo AFM

NEWH... trimtools 20, 45, and 90

Finally, one trimming tool for all of your trimming needs, be it at room or cryo temperatures.

\section{the highest quality....} the most precise sectioning... incomparable durability

\section{DIATOME U.S.}

P.O. Box $550 \cdot 1560$ Industry Rd. • Hatfield, Pa 19440

Tel: (215) 412-8390 - Fax: (215) 412-8450

email: info@emsdiasum.com or stacie@ems-secure.com

www.emsdiasum.com

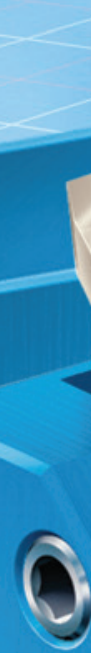


muscle cells and blood vessel-forming cells, the extracellular matrix was processed into a personalized hydrogel. The cells and hydrogel were mixed to generate patient-specific, immunocompatible cardiac patches. Two cellular "bioinks" were generated: the cardiac cell bioink, which was used for printing the parenchymal tissue, and a bioink consisting of blood vessel-forming cells. In this strategy, when using the patient's own materials and cells, the two bioinks may be used to print thick, vascularized, and perfusable patches of cardiac tissue that fully match the immunological, biochemical, and anatomic properties of the patient. Furthermore, the authors demonstrated that the personalized hydrogel can be used to print volumetric, freestanding, cellular structures, including entire hearts with their major blood vessels!

Scanning electron microscopy was used to visualize the ultrastructure of the personalized hydrogel. Fluorescence microscopy was used in a series of immunocytochemical studies to confirm the identities of the differentiated cells. For example, staining for sarcomeric actinin confirmed that the pluripotent cells had differentiated into cardiac myocytes. Confocal microscopy was used to visualize the printed blood vessels within the cardiac patches. Another example demonstrates endothelial cells and fibroblasts (Figure 1a).
These and other results demonstrated the ability to use the patient's own cells and extracellular material for 3D printing of fully personalized contracting cardiac patches that closely fit the patient's biochemical and cellular properties, as well as the anatomy of the patient. This approach can yield structures several millimeters thick, which is sufficient for engineering clinically relevant cardiac patches.

Finally, Noor et al. conducted some proof of concept studies. They fabricated small-scale cellularized human hearts with major blood vessels, based on a digital design. A heart several centimeters in height was constructed. Immunostaining demonstrated the presence of cardiac myocytes and endothelial cells (Figure 1b). Although a great deal of research and development needs to be devoted, this is an elegant first step toward the generation of a functional, mechanically stable organ that may be amenable to clinical applications.

\section{References}

[1] N Noor et al., $A d v S c i$, April 15, 2019, https://onlinelibrary.wiley.com/doi/full/10.1002/advs.201900344.

[2] The author gratefully acknowledges Drs. Nadav Noor and Tal Dvir for reviewing this article.

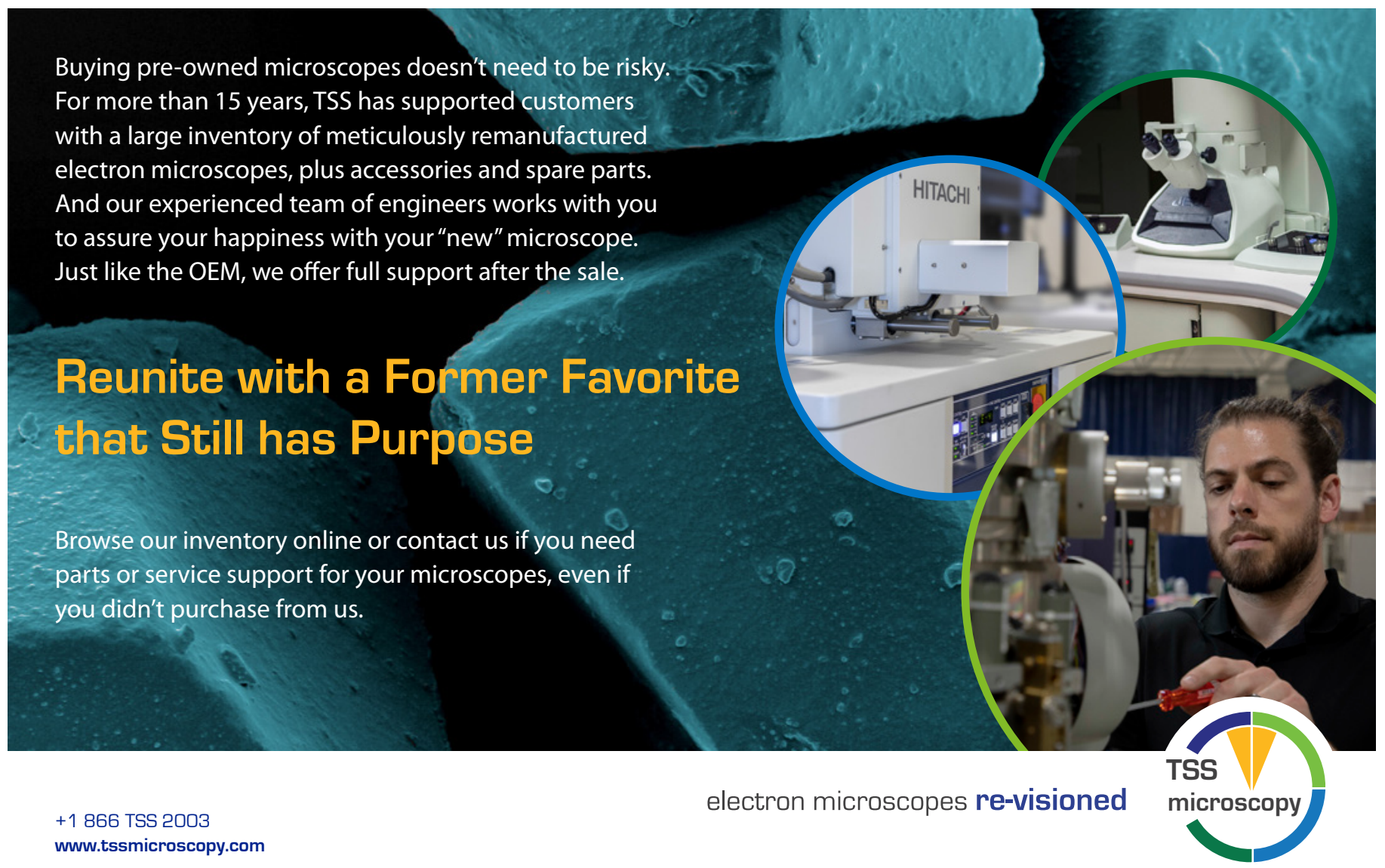




\section{The moment "I think" becomes "I know".}

\section{This is the moment we work for.}

\section{// INNOVATION}

MADE BY ZEISS
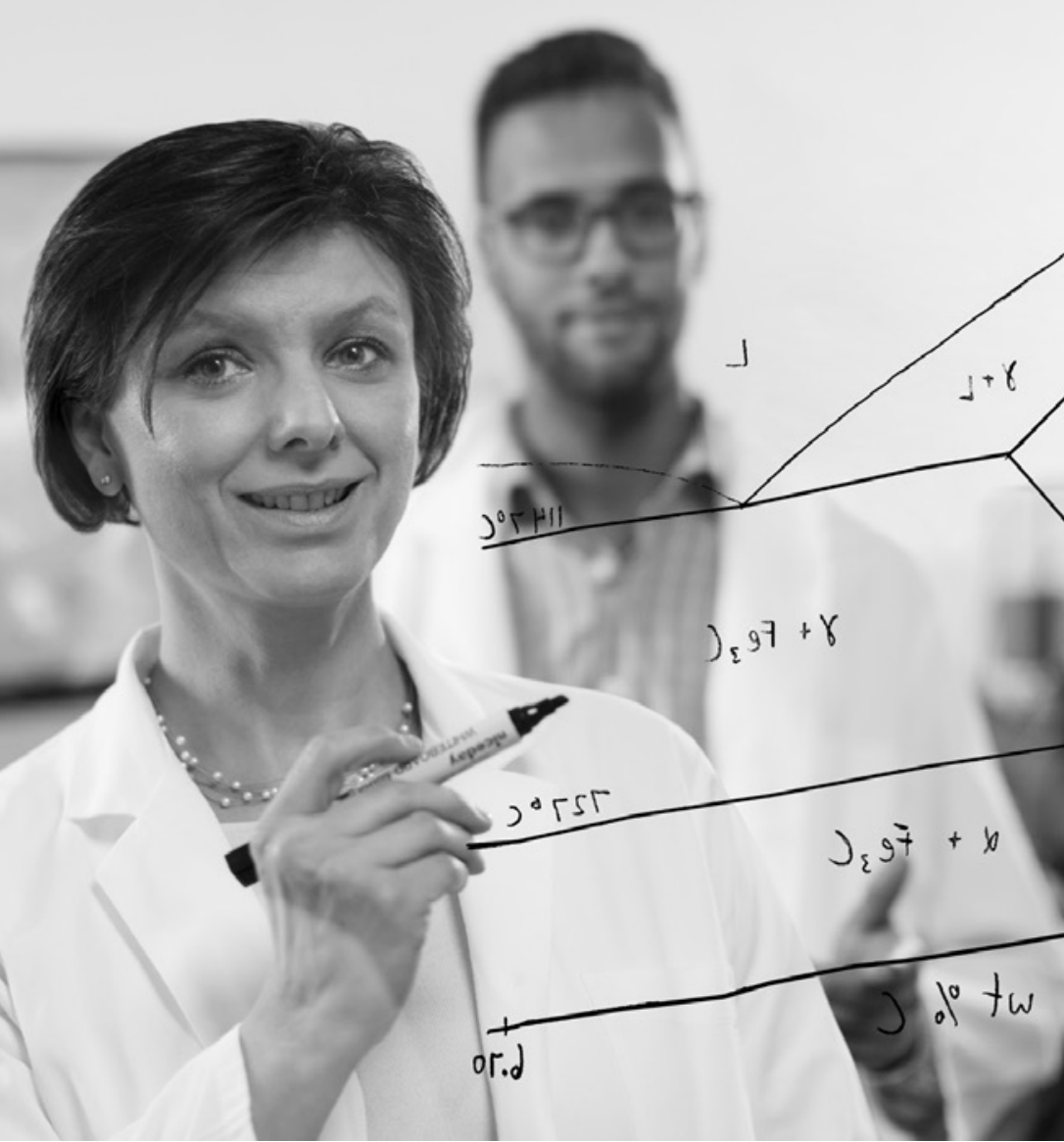

\section{$\partial_{\varepsilon} 9^{7}+x$}

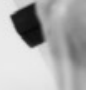

